\title{
GLACIAL AND CLIMATIC EVENTS IN ICELAND REFLECTING REGIONAL NORTH ATLANTIC CLIMATIC SHIFTS DURING THE PLEISTOCENE-HOLOCENE TRANSITION
}

\author{
ÓLAFUR INGÓLFSSON,* SVANTE BJÖRCK, † HAFLIDI HAFLIDASON \\ *Earth Sciences Centre, University of Göteborg, S-413 81 Göteburg, Sweden (E-mail: olafur@geo.gu.se) \\ $\doteqdot$ Geological Institute, University of Copenhagen, Øster Voldgade 10, Dk-1350 Copenhagen K, Denmark \\ $\$$ Geological Institute, University of Bergen, Allégaten 4I, N-5007 Bergen. Norway \\ \$Department of Quaternary Geologv, Lund University, Tornavägen 13, S-223 63 Lund, Sweden
}

\begin{abstract}
This paper presents a summary of the evidence for glacial and climatic changes during the late Pleistocene-early Holocene transition in lceland. The deglaciation during the BøllingAllerød event was interrupted by a short-lived Older Dryas glacial advance. A biostratigraphical record from northern Iceland shows significant climate warming in late Allerød, when mean July temperatures were at least as warm as those of today. An abrupt cooling marked the beginning of the Younger Dryas event. It was characterised by a cold and stable polar climate and an exiensive glaciation, before the postglacial warming of climate set in. The Icelandic paleoclimatic record is discussed in the light of climatic oscillations recorded from the GRIP ice-core. from the Greenland Inland Ice, and with reference to major shifts in the oceanic front systems, recorded in the Troll 8903 marine sediment core from the North Sea. The Vedde Ash gives a unique opportunity to address the chronological problems and correlate event stratigraphies of the different proxies. It is concluded that the Icelandic record of glacial and climatic changes during the late Pleistocene-early Holocene transition largely reflects the climatic development in the North Atlantic region. (C) 1998 Elsevier Science Ltd. All rights reserved
\end{abstract}

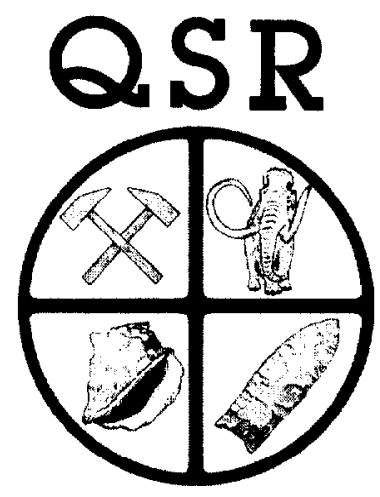

\section{INTRODUCTION}

The climatic and glacial histories of the North Atlantic region during the last deglaciation have, for the past two decades, to a large extent been interpreted in terms of time-transgressive shifts in the North Atlantic oceanic Polar Front (Ruddiman and McIntyre, 1981; Karpuz et al., 1993). Variations in the position of the Polar Front have been ascribed to reflect a number of large-scale oceanographic changes, such as the operation of the thermohaline ocean conveyor (Broecker and Denton, 1990), sudden influx of freshwater from melting ice sheets (Broecker et al., 1989) and energy transfer in connection with the formation of deep-water in the North Atlantic (Broecker et al., 1985). There are a number of feedback mechanisms active in the system, and the significant effects of Late Quaternary ice sheets and sea ice cover on atmospheric and surface ocean circulation have been pointed out (Kutzbach and Wright, 1985; Karpuz and Jansen, 1992). Another proxy for climatic and environmental changes in the North Atlantic region during the Late Weichselian and early Holocene are the Greenland ice cores. These contain a record which shows climatic changes roughly in phase with the fluctuations of the oceanic Polar Front (Dansgaard et al., 1989, 1993;
Alley et al., 1993; Meese et al., 1994; Johnsen et al., 1995; Haflidason et al., 1995). The ice-core record implies that large-scale climatic changes can occur very rapidly, an inference supported by recent studies of North Atlantic deep sea sediments and NW European peat deposits and coleopteran remains (Bond et al., 1993; Thouveny et al., 1994; Coope and Lemdahl, 1995). Lowe et al. (1994) concluded that regional patterns in temperature conditions from North Atlantic seaboard areas fitted closely with the Ruddiman and McIntyre (1981) model of oceanic surface temperature changes during the last glacial-interglacial transition.

The movements of the North Atlantic Polar Front during the last glacial-interglacial transition have been described as evolving around 'hinges' located in the western North Atlantic (Fig. 1), with a much greater arc of north-south movement in the eastern sector as compared to the western sector (Lowe et al., 1994). Iceland's position in the middle of the North Atlantic Ocean makes its climate and glaciers highly sensitive to changes in the oceanic and atmospheric front systems. The Polar Front oscillations through time have periodically put Iceland in the Boreal or Arctic marine domains, as defined zoogeographically by Feyling-Hanssen (1955), or at the boundary between these domains as is the 


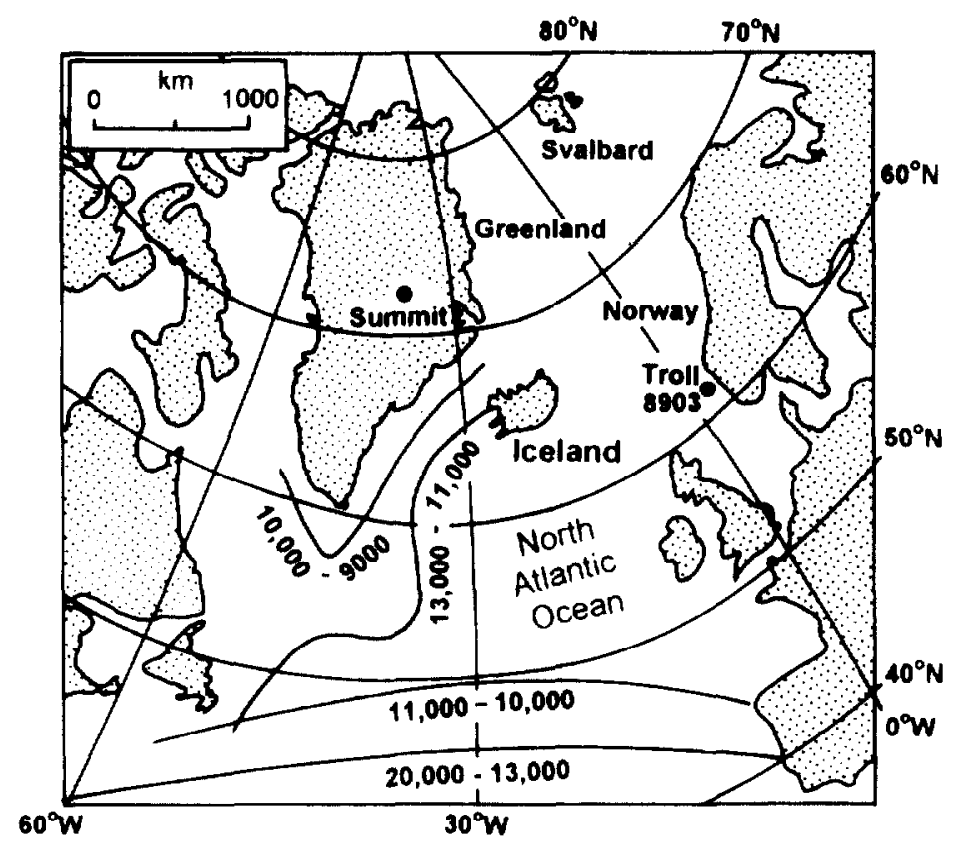

FIG. 1. Iceland in the mid-North Atlantic and the approximate location of the Troll 8903 sediment core and the GRIP Summit ice core. Polar Front movements, in uncalibrated radiocarbon years BP, after Ruddiman and McIntyre (1981).

situation today. It has been suggested that the deglaciation history of Iceland broadly fitted with the Ruddiman and McIntyre (1981) perception of oceanic surface temperature changes during the last glacial-interglacial transition as well as with the Greenland ice-core data on climate oscillations at the end of the Late Weichselian glaciation (Ingólfsson, 1988; Sveinbjörnsdóttir and Johnsen, 1991; Ingólfsson and Norddahl, 1994). However, due to the relatively low resolution of the Icelandic data on the last glacial-interglacial transition, this suggestion has been difficult to test.

The purpose of this paper is to present a summary of the evidence for glacial and climatic changes during the late Pleistocene-early Holocene transition on Iceland and investigate it in the light of recent data from deep-sea sediment cores and the Greenland GRIP deep ice-core. A new high-resolution terrestrial biostratigraphical record from northern Iceland (Björck et al., 1992: Rundgren, 1995), together with new information on tephra horizons in the Icelandic terrestrial record (Björck et al., 1992; Norddahl and Ilaflidason, 1992) and the GRIP core (Grönvold et al., 1995), as well as recent data from the high resolution sediment core Troll 8903 from the North Sea (Haflidason et al., 1995), make correlations between these different environments possible.

A major problem when attempting to correlate environmental development between different types of proxies is one of chronology. The deglaciation chronology and history of relative sea-level changes in Iceland is based on ${ }^{14} \mathrm{C}$ dates of subfossil marine molluses in coastal deposits (Ingólfsson, 1991; Norddahl, 1991a). where a sea correction of 365 years (Håkansson, 1983) is applied. The chronology for climate and vegetation history in connection with the deglaciation is based on ${ }^{14} \mathrm{C}$ dates of bulk sediments or macrofossils from lake sediment cores or peat deposits (Björck et al., 1992; Rundgren, 1995; Ingólfsson et al., 1995). Rundgren (1995) has shown that the boundary between the Allerød and Younger Dryas events in Iceland, dated to ca. 11,000 BP by marine molluse dates (Ingólfsson, 1988) has a ${ }^{14} \mathrm{C}$ age of ca. $10,600 \mathrm{BP}$ in limnic sediments. This discrepancy in the dating of the event boundary is most likely in part an effect of a poorer time resolution and stratigraphical control of the mollusc-based chronology as compared to the lake sediment record, and partly due to changes in the marine reservoir effect over time. According to Bard et al. (1994) and Haflidason et al. (1995) the marine reservoir age was ca. 800 years in the North Atlantic Ocean and the Norwegian Sea during the Younger Dryas climatic event, compared to ca. 400 years today.

The occurrence and age of the widely used time marker, the Vedde Ash, in the different environments highlight the discrepancies in chronologies between the ice core record and the ${ }^{14} \mathrm{C}$ chronology for the marine and terrestrial record on the one hand, and between the lacustrine and marine ${ }^{14} \mathrm{C}$ chronologies on the other. The Vedde Ash, first described and dated in Norway and the Facroc Islands by Mangerud et al. (1984, 1986), probably originates from either of the Icelandic volcanoes (Fig. 2A) Mt. Öraefajökull (Norddahl and Haflidason, 1992) or Mt. Katla (Lacasse et al., 1995). It has been recognised as a constituent of Ash zone I in North Atlantic and Norwegian Sea sediment cores (Jansen, 1987; Kvamme et al., 1989; Sejrup et al., 1989; Karpuz and Schrader, 1990; Sjøholm et al., 1991), and found in cores from the North Sea (Long and Morton, 1987), as well as been described from a number of localities in Iceland (Norddahl, 1991b; Björck et al., 1992; Norddahl and Haflidason, 1992; Lacasse et al., 1995). The Vedde Ash has also been described from the terrestrial record from NW-Europe (Bard et al.. 1994). It has recently been recognised in the GRIP ice core from Greenland (Grönvold et al., 1995) and as a separate tephra horizon in sediment core Troll 8903 from the North Sea 
A

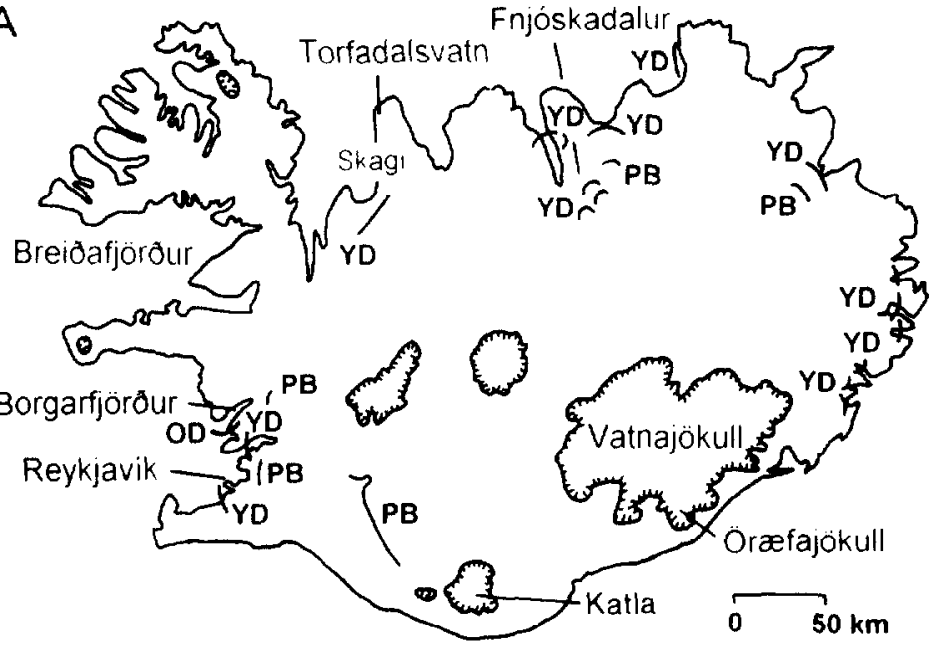

Legend $O D$ Older Dryas ice margin

YD. Younger Dryas ice margins

PB Preboreal ice margins

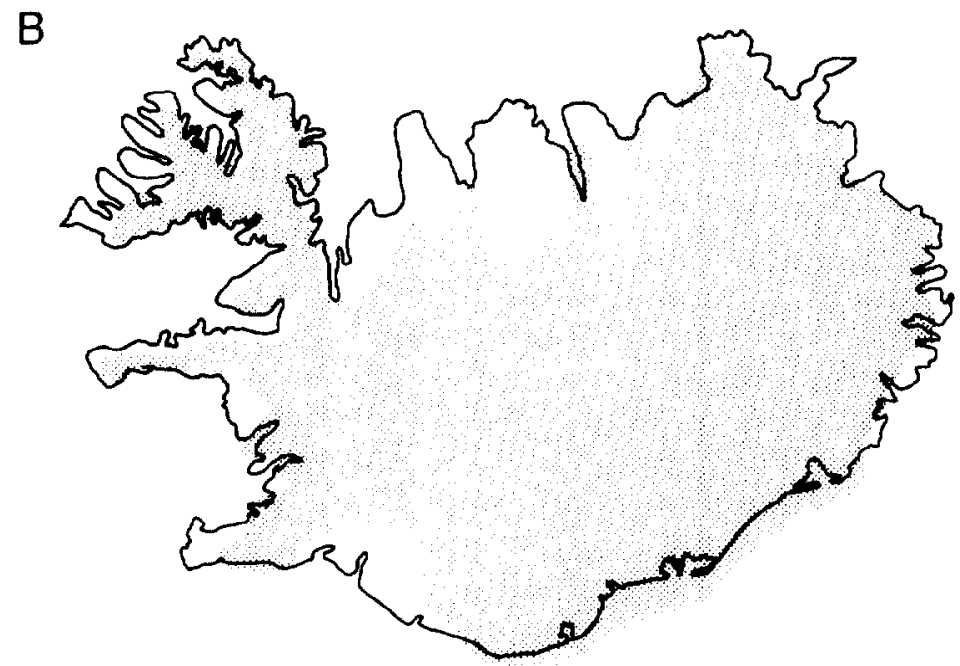

FIG. 2. (A) Ice marginal positions in Iceland during the Older Dryas, Younger Dryas and early Preboreal. Location of sites mentioned in the text. (B) The extent of ice cover in Iceland during the Younger Dryas glacial event.

(Haflidason et al.. 1995). In the GRIP ice core, the Vedde Ash is present at 11,980 calendar years (Grönvold et al., 1995). In the marine record, the best age estimate for the Vedde Ash in the high-resolution Troll 8903 core is $10,660 \pm 110 \mathrm{BP}$, based on an AMS date made on foraminifera and corrected for a reservoir age by 440 years, but around 10,300 BP when a sea correction of 800 years is applied (Haflidason et al., 1995). In the terrestrial record, the atmospheric ${ }^{14} \mathrm{C}$ age for the Vedde Ash, dated by AMS dates on macrofossils from limnic sediments in Norway, is 10,300 BP (Bard et al., 1994). The only age determination for the Vedde Ash on Iceland comes from lake sediments on Skagi, northern Iceland (Fig. 2A; Björck et al., 1992), where an AMS date made on bulk sediments sampled $17 \mathrm{~cm}$ below the Vedde Ash gave it a maximum age of $10,550 \pm 240 \mathrm{BP}$.

Our approach to investigate evidence for glacial and climatic changes during the late Pleistocene-early Holocene transition in Iceland in the light of recent data on environmental changes from the GRIP ice-core and the
Troll 8903 sediment core, is to compare events in the stratigraphical records, using the Vedde Ash as a time marker horizon, rather than depending on absolute chronologies.

\section{THE LATE PLEISTOCENE-EARLY HOLOCENE TRANSITION IN ICELAND}

The late Pleistocene-early Holocene transition in the Icelandic stratigraphic data is the period from mid Bølling times, when glaciers for the first time during the Late Weichselian retreated to positions within the present coastline, up to the Preboreal-Boreal boundary, when the present interglacial climate had become established (Björck et al., 1992; Ingólfsson and Norddahl, 1994; Rundgren, 1995). The extent of the Icelandic ice sheet during the Late Weichselian maximum glaciation is poorly known, because ice margins were off the present shore. Probably the ice partly grounded close to the shelf 
edge at ca. $200 \mathrm{~m}$ below present sea level and partly was drained through troughs on the shelf. Ice-free nunataks existed and erosion prevailed inside the present coast. Our estimate of ice thickness during the maximum glaciation, based on Walker's (1965) reconstruction of the ice cap profile and Einarsson's $(1968,1991)$ reconstruction of the ice divides, is that it only exceeded $1000 \mathrm{~m}$ in southeastern Iceland, in the vicinity of the present-day Vatnajökull (Fig. 2A), and was less in other parts of the country. The north-western peninsula probably carried a separate, relatively thin ice sheet.

\section{The Bølling-Allerod Event}

The onset of glacial retreat from positions on the shelf has not been dated in Iceland, but around mid-Bølling times coastal areas were becoming ice-free. Marine sediments of that age have been described from areas within the present south-west coast (Ashwell, 1967; Ingólfsson, 1988) and north-east coast (Einarsson, 1968; Pétursson, 1986, 1991). The relative sea-level was high, at least $90 \mathrm{~m}$ a.s.l. on the outer coast in south-western Iceland (Ingólfsson, 1987, 1988), and maybe as high as ca. $150 \mathrm{~m}$ a.s.l. further inland (Ashwell, 1967).

As yet no terrestrial biostratigraphical record on Iceland extends back to the Bølling, but few studies exist on the marine climate immediately following the deglaciation of the coastal areas. Ingólfsson (1987, 1988) described a boreal-arctic Macoma calcarea mollusc community from glaciomarine sediments in Borgarfjördur, south-western Iceland (Fig. 2A), radiocarbon dated to $12,500-12,000 \mathrm{BP}$. Most individuals of $M \mathrm{va}$ truncata belong to form uddevallensis, which is a thickshelled, panarctic, circumpolar fauna, not present in Icelandic coastal waters today. The clam Chlamys islandica, which is an indicator of Atlantic boreal-arctic waters, also occurs. Ingólfsson (1988) suggested that sea temperatures during the $\mathrm{B} \emptyset l$ ling had been somewhat lower than $+5 \mathrm{C}$, which is the average sea temperature in the area today. Sveinbjörnsdóttir and Johnsen (1991) calculated paleotemperatures from $\delta^{18} \mathrm{O}$ of radiocarbon dated shells of B 6 lling age from south-western Iceland, and concluded that sea temperatures were not higher than $+2 \mathrm{C}$. Both these studies indicate that the marine Polar Front was situated north of western Iceland at that time.

During the Allerød, glaciers in fjords and valleys around Iceland probably terminated close to the present coast (Ingólfsson and Norddahl, 1994), but there were relatively large ice-free areas on coastal mountains and peninsulas, especially in northern Iceland. A glacier advance between 12,000 and 11,800 BP in Borgarfjördur, south-western lceland (Ingólfsson, 1987), reached a position seawards of the present coast. This advance, which is well constrained with radiocarbon dates (Fig. 3), coincides in the radiocarbon time scale with the Older Dryas climatic event in NW-Europe. Relative sea level was higher than the present throughout the Allerod, and the lowlands on southern Iceland were probably ice-free but submerged. A number of studies highlight the nearshore marine environment in late Allerod times in Iceland. Eiríksson et al. (1991) described a marine macrofauna from sediments deposited close to the Allerød-Younger Dryas transition (Hjartarson, 1989) in the Reykjavík area (Fig. 2A). The species recognised all live in low arctic-high boreal Icelandic waters today, and Eiríksson et al. (1991) concluded that the marine environment at the time of deposition of these sediments was similar to today's environment in terms of temperature and salinity. Paleotemperature estimates by Sveinbjörnsdóttir and Johnsen (1991), based on samples from the same sediments as those studied by Eiríksson et al. (1991) give mean near-shore sea temperatures of $+2.4^{\circ} \mathrm{C}$, varying between $0.2 \mathrm{C}$ and $5.4 \mathrm{C}$. Bárdarson (1921) and Andrésdóttir (1987) described deposits from the Breidafjördur area, western Iceland (Fig. 2A), dated to ca. 11,300 BP by Kjartansson (1966), with a marine macrofauna containing the arctic mollusc species Portlandia arctica.

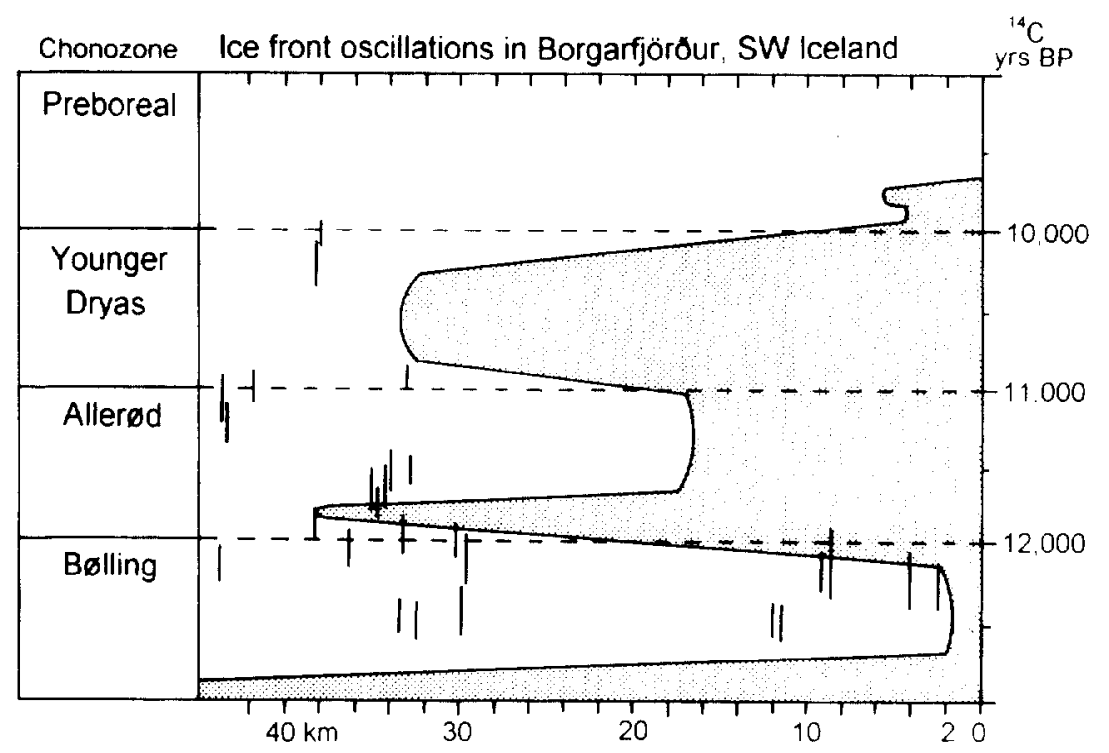

FIG. 3. Time-distance diagram for glacial oscillations in the Borgarfjördur area, western Iceland. ${ }^{14} \mathrm{C}$ dates plotted with one sigma standard deviation. Modified from Ingólfsson (1988). 


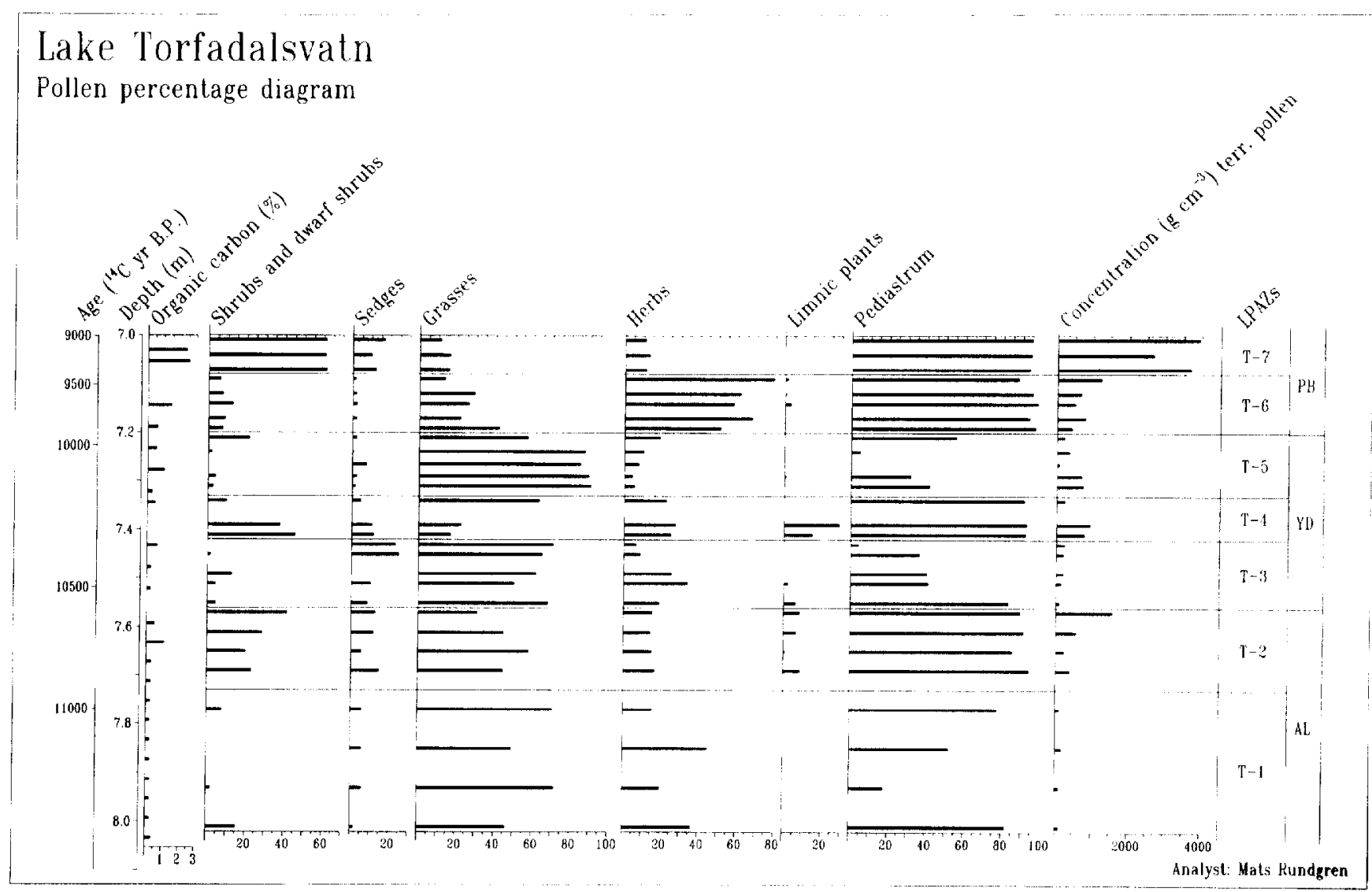

FIG. 4. A simplified pollen diagram from Lake Torfadalsvatn. Skagi, northern Iceland. Modified from Rundgren (1995). Pollen zone T4 resulted from redeposition of older (mainly T-2) sediments, and is disregarded in the interpretation of the climatic record (Rundgren, 1995).

In a recent study by Ásbjörnsdóttir and Norddahl (1995), the foraminiferal content of sediments of late Allerød age from the Breidafjördur area was used to interpret the marine climate at the time of deposition. They concluded that nearshore marine temperatures in the late Allerød were lower than present sea surface temperatures. There is a substantial presence of arctic foraminiferal species in the sediments, which they suggest might reflect nearshore cooling by glacial meltwater. Ingólfsson (1987. 1988) described glaciomarine sequences from the Borgarfjördur area, south-western Iceland, dated to around $11,000 \mathrm{BP}$, that carries arctic faunal species (Portlandia arctica and Buccinum groenlandicum), indicating cooler waters than today's. However, since molluscs in sediments of similar age from the Reykjavík area, only about $50 \mathrm{~km}$ south of the Borgarfjördur sites, are indicative of high boreal to low arctic waters, possibly the marine macrofauna in Borgarfjördur was influenced by cold glacial meltwater input to the nearshore environment, as well as reduced salinity. Taken together, studies of sediments and their marine fauna indicate that the sea surface temperatures in western Iceland were similar to or somewhat lower than today's temperatures in late Allerød times, and that the marine Polar Front was situated north of western Iceland.

The oldest continuous terrestrial record from lake sediments on Iceland comes from Lake Torfadalsvatn on the Skagi peninsula, northern Iceland (Fig. 2A), and extends back to mid-late Allerød times (Björck et al.,
1992; Rundgren, 1995). The biostratigraphy first records pioneer vegetation when grasses and fell-field herbs became established (Fig. 4). The plant cover was sparse and the climate cold. The vegetation was similar to pioneer vegetation occurring on nunataks and in front of Icelandic glaciers today (Rundgren, 1995), and possibly there were glaciers close to the Skagi site in mid-Allerød times. Productivity in and around the lake was low, and there are indications of long seasons with ice cover on the lake. By late Allerød, climatic and soil conditions on the Skagi peninsula were lavourable for shrub and dwarfshrub growth, and for a period of ca. $300{ }^{14} \mathrm{C}$-years the taxa recorded from the lake sediments indicate that airtemperatures during the warmest month may have reached $10^{\circ} \mathrm{C}$ (Rundgren, 1995). Today's average July temperature is ca. $9^{\circ} \mathrm{C}$, so the climate was at least as warm as that of today. This suggests long scasons with open ocean conditions in the Greenland Sea, immediately north of Iceland, indicating a northward displacement of the Polar Front.

\section{The Younger Dryas Glacial and Climatic Event}

The Icelandic morphostratigraphical and lithostratigraphical records show pronounced ice advances around the whole island in Younger Dryas times. The onset of this event is not known, except that it started later than 11.000 $\mathrm{BP}$ as dated by the mollusc-based ${ }^{14} \mathrm{C}$ chronology 
(Ingólfsson, 1988; Ingólfsson and Norddahl, 1994). The ice sheet reached close to or beyond the present shoreline around most of the island (Fig. 2B). Elevated coastal mountains and peninsulas were ice free. Relative sea level was high, and ice-free lowlands in southern and northern Iceland were submerged by the sea. The climatic development in connection with the Younger Dryas glacial event is recorded in the lake sediments from Skagi. The biostratigraphical record (Fig. 4) shows a dramatic drop in pollen influx and organic carbon in connection with the onset of the Younger Dryas event (Rundgren, 1995). The terrestrial vegetation changed and became similar to that during the pioneer phase in midAllerød. The climate was cold and stable for the rest of the Younger Dryas event, indicating heavy sea-ice conditions north of Iceland and that the Irminger branch of the Gulf Stream had been shut off.

In the Skagi record, the Vedde Ash enters the lake sediments well into the Younger Dryas event, when polar climate had set in. In Fnjóskadalur on central north Iceland (Fig. 2A), the Vedde Ash was deposited in iceproximal lacustrine sediments and on deltas (Norddahl, 1983, 1991b) and can be used to give maximum ages for two subsequent Younger Dryas glacial advances in that region (Norddahl and Haflidason, 1992). Thus the terrestrial biostratigraphical record from Skagi can be correlated to the event stratigraphy of Fnjoskadalur.

\section{The Final Deglaciation and Preboreal Development}

The deglaciation of coastal Iceland, as recorded in the stratigraphical record and dated on subfossil marine molluscs, occurred between 10,300 BP and ca. 9600 BP, with earlier deglaciation in western Iceland and later in southern, northern and eastern Iceland (Ingólfsson, 1991; Norddahl, 1991a; Ingólfsson and Norddahl, 1994). There are indications from a number of localities around Iceland of an early Preboreal glacial advance (Figs 2A and 3) or halt in glacial retreat (Ingólfsson, 1988; Hjarlarson and Ingólfsson, 1988; Norddahl, 1991a; Norddahl and Haflidason, 1992; Sæmundsson, 1995; Norddahl and Ásbjörnsdóttir, 1995). This glacial event has been dated in southern Iceland to around $9700 \mathrm{BP}$ (Hjartarson and Ingólfsson, 1988). The limnic biostratigraphical record from Skagi dates the climatostratigraphical boundary between Younger Dryas and Preborcal to $9900 \mathrm{BP}$, and indicates that the early Preboreal climate there was cool, with long seasons with open ocean conditions north of Iceland (Rundgren, 1995). Detailed organic carbon and pollen analysis of three lake sediment cores from Skagi have revealed an early Preboreal cold phase and associated minor marine transgression, which Rundgren et al. (1997) relate to a short-lived phase of glacier growth. The Skagi record shows a marked warming starting at around $9400 \mathrm{BP}$ on northern Iceland (Rundgren, 1995), and after that there are no indications in the record of annual sea ice immediately north of Iceland.

\section{DISCUSSION AND SUMMARY}

The late Pleistocene-early Holocene climatic and glacial development on Iceland is summarised in Fig. 5, and our proposal for correlations with the GRIP ice core record and the marine record from sediment core Troll 8903 is shown in Fig. 6. The occurrence of the Vedde Ash in the ice/sediment cores as well as in the Icelandic stratigraphy allows direct correlations.

Comparison between the Icelandic record, as expressed in the glaciation and inferred temperature curves, the GRIP ice core stable oxygen isotopes (mean $\delta^{18} \mathrm{O}$ ) and the Neogloboquadrina pachyderma record from the Troll 8903 core, using the Vedde Ash as a regional stratigraphic marker, reveals some striking similarities in the records (Fig. 6):

(1) The Icelandic record indicates a dominance of relatively warm Atlantic water during the BøllingAllerød, with a short cooling period corresponding to the Older Dryas, but that open ocean conditions prevailed during much of the year by the end of Allerød. Although correlations between the three proxies are uncertain for the Bølling-Allerød, the Older Dryas glacial advance on Iceland could possibly correspond to a drop in $\delta^{18} \mathrm{O}$ in the GRIP core and a rise in $N$. pachyderma in the Troll 8903 core in mid Bølling-Allerød (Fig. 6). Both the GRIP and the Troll 8903 records indicate climatic instability during the Bølling-Allerød, with periodic cold spells in an overall relatively warm climate. Reconstructions of oceanographic circulation in the North Atlantic (Karpuz and Jansen, 1992; Karpuz et al., 1993) show that the marine polar front was located close to Iceland during the Bølling and Allerød. The combined Icelandic biostratigraphical data (marine and terrestrial) for the Bølling and Allerød also fits well with a recent reconstruction by Sarnthein et al. (1995) of North Atlantic paleotemperature estimates, where it is concluded that sea surface circulation was largely in Holocene-style interglacial mode after $12,800 \mathrm{BP}$.

(2) An abrupt cooling marks the beginning of the Younger Dryas event. The Icelandic terrestrial record shows a relurn from mild climatic conditions by the end of Allerød to polar climatic conditions and extensive ice advances in connection with the Younger Dryas event. The dramatic drop in pollen influx and content of organic carbon in lake sediments on northern Iceland indicate rapid change of climate. The presence of the Vedde Ash in stratigraphical archives on Iceland as well as in the GRIP and Troll 8903 records makes correlations between the proxies fairly certain. The ice-core records show a drop in mean annual temperatures in central Greenland of at least $15^{\circ} \mathrm{C}$ at the onset of the Younger Dryas event (Johnsen et al., 1995), and foraminiferal and diatom data from deep-sea cores show a major southward penetration of polar water and fall in sea surface temperatures (Lehman and Keigwin, 1992; Karpuz and Jansen, 1992; Haflidason 
Ó. Ingólfsson et al.: Glacial and Climatic Events in Iceland

\begin{tabular}{|c|c|c|c|c|c|c|}
\hline $\begin{array}{c}\text { Climato- } \\
\text { stratigraphy }\end{array}$ & $\begin{array}{l}\text { Glacial ice cover } \\
\text { in coastal areas } \\
\text { extensive limited }\end{array}$ & $\begin{array}{c}\text { Terrestrial } \\
\text { (Skagi, nort) } \\
\text { Dominant } \\
\text { vegetation }\end{array}$ & $\begin{array}{l}\text { environment } \\
\text { Plant cover }\end{array}$ & $\begin{array}{l}\text { Climatic / coastal } \\
\text { conditions }\end{array}$ & $\begin{array}{l}\text { Polar front } \\
\text { position }\end{array}$ & $\begin{array}{c}\text { Paleo- } \\
\text { temperature } \\
\text { Mean July } \\
\text { temperature }{ }^{\circ} \mathrm{C}\end{array}$ \\
\hline Preboreal & & $\begin{array}{c}\text { shrubs \& } \\
\text { dwarf shrubs } \\
\\
\text { pioneer plants } \\
\text { herbs \& } \\
\text { grasses } \\
\end{array}$ & \begin{tabular}{|l|} 
continuous \\
discontinuous
\end{tabular} & $\begin{array}{l}\text { mild - no annıal } \\
\text { sea ice } \\
\text { rapid warming } \\
\text { cool - long seasons } \\
\text { without sea ice }\end{array}$ & $\begin{array}{l}\text { north of Iceland } \\
\text { north of Iceland }\end{array}$ & U \\
\hline $\begin{array}{c}\text { Younger } \\
\text { Dryas }\end{array}$ & $\begin{array}{c}\text { Vedde } \\
\text { Ash }\end{array}$ & $\begin{array}{c}\text { grasses } \\
\begin{array}{c}\text { grasses \& } \\
\text { herbs }\end{array} \\
\end{array}$ & \begin{tabular}{|c|} 
discontinuous \\
sparse \\
\end{tabular} & $\begin{array}{l}\text { cold - short seasons } \\
\text { without sea ice } \\
\text { abrupt cooling - } \\
\text { Arctic molluscs }\end{array}$ & $\begin{array}{l}\text { south of Iceland } \\
\text { south of Iceland }\end{array}$ & \\
\hline Allerød & & $\begin{array}{c}\text { shrubs \& } \\
\text { dwarf shrubs } \\
\text { pioneer plants } \\
\text { grasses \& } \\
\text { nerbs }\end{array}$ & $\begin{array}{c}\text { discontinuous } \\
\text { sparse }\end{array}$ & $\begin{array}{c}\text { mild (July temp. } 10^{\circ} \mathrm{C} \text { ) } \\
\text { - Iong seasons without } \\
\text { sea ice } \\
\text { Boreal-arctic molluscs } \\
\text { cold - Influence of } \\
\text { local glaciers }\end{array}$ & $\begin{array}{l}\text { north of Iceland } \\
\text { (?) }\end{array}$ & \\
\hline Bølling & & & & $\begin{array}{l}\text { Boreal-arctic molluscs } \\
\text { cool - annual sea ice } \\
\text { cold - glacial climate }\end{array}$ & $\begin{array}{l}\text { north of Iceland } \\
\text { south of Iceland }\end{array}$ & \\
\hline
\end{tabular}

FIG. 5. Summary of the glacial and climatic record of Iceland during the late Pleistocene-early Holocene transition. The relative glaciation curve is modified from Ingólfsson and Norddahl (1994). The temperature curve is mainly based on biostratigraphical data from subfossil marine molluscs and foraninifera, reflecting nedr-shore Indrine tenperatures (Ingólfsson, 1988; Eiriksson et al., 1991; Ásbjörnsdóttir and Norddahl, 1995), and on the lake sediment record from Skagi (Rundgren, 1995), reflecting summer temperatures in northern Iceland.

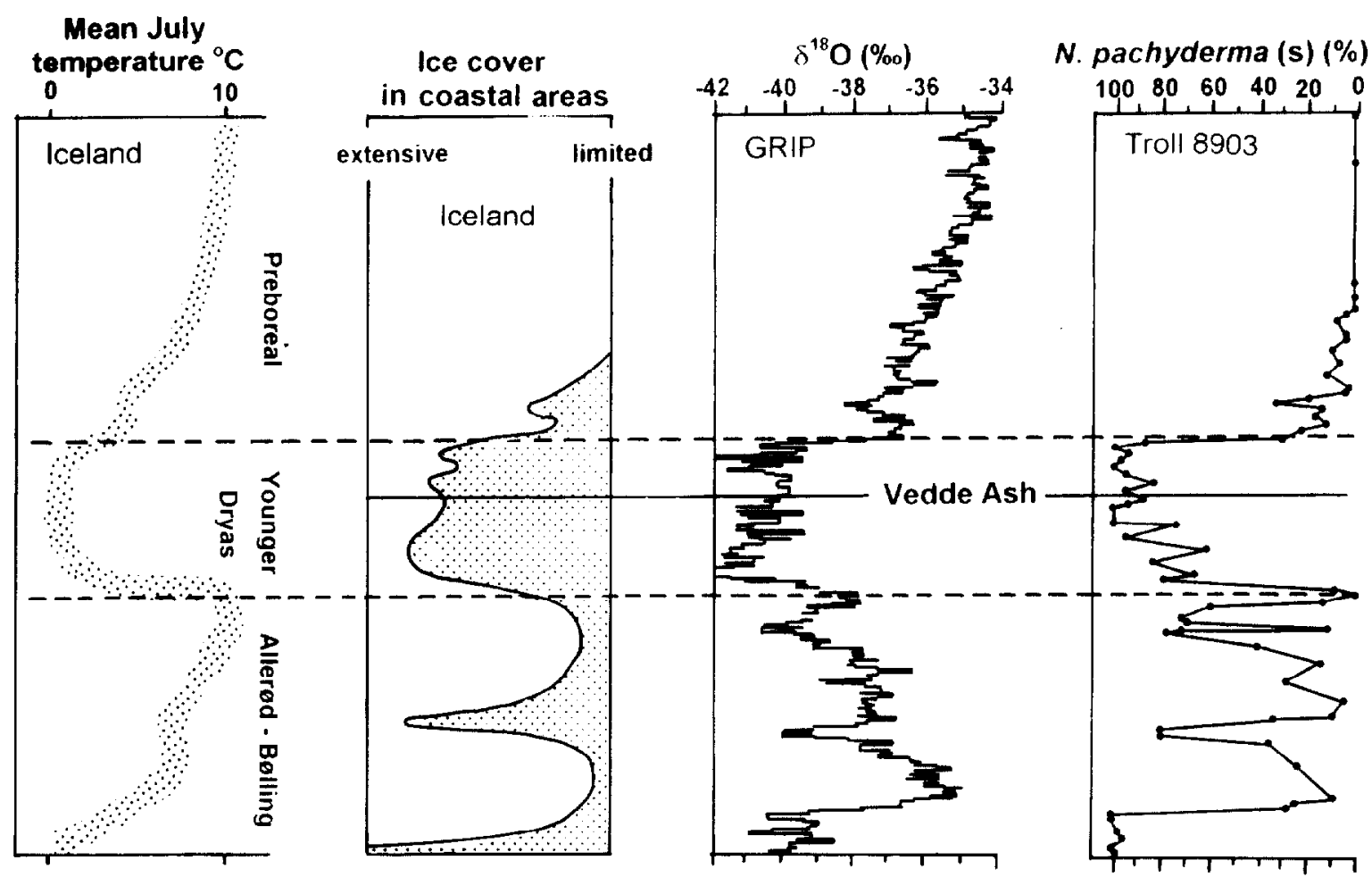

FIG. 6. Comparison of the Icelandic environmental record, the oxygen stable isotopes record from the GRIP deep ice core and the $N$. pachyderma record from sediment core Troll 8903. The calibration of the GRIP and Troll 8903 records is from

Haflidason et al. (1995). 
et al., 1995). According to Sarnthein et al. (1995), the Younger Dryas was a period of extreme seasonality bccause of a closed sea ice cover during winter, which fits well with our interpretations of Younger Dryas coastal conditions in Iceland (Fig. 5).

(3) The evidence from the Troll 8903 core along with the Greenland ice core record confirm that changes from a glacial to an interglacial regime took place in as short a time as 10 years or less, and that the reverse changes occurred at a time scale of 25 years or less (Alley et al., 1993; Haflidason et al., 1995). The Icelandic record does not yet have this high resolution, and probably both glaciers and vegetation on Iceland lag in response to the atmospheric and oceanic changes. The climatic deterioration in connection with the onset of the Younger Dryas event on Iceland was very rapid, and we conclude that the glacial and climatic record from Iceland fits reasonably well with both the isotopic record from the GRIP core and the foraminiferal record from sediment core Troll 8903. The good fit of data from these different proxies suggests that climatic changes in the whole North Atlantic region during the last glacial-interglacial transition were driven by the same climatic forcing mechanism, and that there is a close correspondence between movements of the marine Polar Front and atmospheric conditions.

(4) The Preboreal on Iceland was primarily a period of ameliorating climate, as reflected by both the glacial retreat history and terrestrial biostratigraphic record from Skagi (Ingólfsson and Norddahl, 1994; Rundgren, 1995). The Preboreal terrestrial record presented by Rundgren (1995), suggesting long seasons with open ocean conditions north of Iceland after ca. 9900 $\mathrm{BP}$, is consistent with the paleoceanographic data on sea surface temperatures from the Greenland Sea (Sarnthein et al., 1995) and shows that the marine Polar Front had re-established itself in an interglacial position north of Iceland as suggested by Karpuz and Jansen (1992). The deglaciation was interrupted briefly by a glacial advance and/or halts in the retreat of the icefronts in early Preboreal time, which could coincide with a fall in $\delta^{18} \mathrm{O}$ in the GRIP core and rise in the percentage of $N$. pachyderma in the Troll 8903 core. After ca. $9600 \mathrm{BP}$, as dated by marine mollusc shells in southern Iceland (Hjartarson and Ingólfsson, 1988), the deglaciation was very rapid. The $9400 \mathrm{BP}$ climate warming suggested by Rundgren (1995) can possibly be correlated with the establishment of diatoms in the deep sea cores from the Icelandic plateau in Preboreal times (Karpuz et al., 1993) on the basis of the occurrence of a tephra layer termed TV-3 occurring in deep sea cores and in lake sediments from Skagi (Björck et al., 1992). By the end of the Preboreal, the transition from glacial to interglacial climate, as reflected in terrestrial and lake vegetation, was completed on northern Iceland (Rundgren, 1995), and by ca. 8000 BP, glaciers were of similar size as today or smaller (Kaldal and Víkingsson, 1991).
(5) It has been shown by Björck et al. (1992) that Ash Zone 1 in Iceland consists of at least five different tephra populations, recognised in lake sediments from Skagi, northern Iceland, deposited over a period of ca. $1500{ }^{14} \mathrm{C}$ years. At least two of these (the Vedde Ash and the Saksunarvatn Ash) have been recognised in the GRIP core (Grönvold et al., 1995). Attempts are now in progress to consolidate the correlations between the Skagi lake cores and the GRIP core, using more tephra layers. The use of tephra horizons as time markers for regional correlations between terrestrial sediments-, ice-cores and deep-sea cores opens up new possibilities to investigate leads and latgs in the glacier-ocean-climate system, as well as highlighting differences between the ${ }^{14} \mathrm{C}$ chronologies from marine and limnic environments and the ice core chronology.

\section{ACKNOWLEDGEMENTS}

The Swedish Research Council finances the research of Ó. Ingólfsson, and has supported this project. The Royal Physiographic Society in Lund and the Science Foundation of Iceland partly financed the work on Iceland.

\section{REFERENCES}

Alley, R. B., Meese, D. A. and Shuman, C. A. (1993) Abrupt increase in Greenland snow accumulation at the end of the Younger Dryas event. Nature 362, 527-529.

Andrésdóttir, A. (1987) Glacial geomorphology and raised shorelines in the Skarosströnd-Saurbær area, West Iceland. Eksamensarbeten i Geologi vid Lunds Universitet, 25 pp. Geologiska Institutionen. Lund.

Ásbjörnsdóttir, L. and Norddahl, H. (1995) Götungar í Sjávarsetlögum vid Mela á Skardsströnd. In Evjar i Eldhafi, eds B. Hróarsson, D. Jónsson and S. S. Jónsson, pp. 179-188. Gott Mál. Reykjavík.

Ashwell, I. Y. (1967) Radiocarbon ages of shells in the glaciomarine deposits of Western Iceland. Geographical Journal 133, 48-50).

Bard, E., Arnold. M., Mangerud, J., Paterne, M., Labeyrie, L., Duprat, J., Mélières, M.-A., Sønstegaard, E. and Duplessy, J.C. (1994) The North Atlantic atmosphere-sea surface ${ }^{14} \mathrm{C}$ gradient during the Younger Dryas climatic event. Earth and Planetary Science Letters 126, 275-287.

Bárdarson, G. G. (1921) Fossile Skalaflejringer ved Breidafjördur i Vest-Island. Geologiska Föreningens i Stockholm Förhandlingar 43, 323-380.

Björck, S., Ingólfsson, Ó.. Haflidason, H., Hallsdóttir, M. and Anderson, N. J. (1992) Lake Torfadalsvatn: a high resolution record of the North Atlantic ash zone I and the last glacialinterglacial environmental changes in Iceland. Boreas 21, 1522.

Bond, G., Broecker, W. S., Johnsen, S. J., McManus, J., Labeyrie, L.. Jouzel, J. and Bonani, G. (1993) Correlations between climate records from North Atlantic sediments and Greenland ice. Nature 365, 14,3-147.

Broecker, W. S. and Denton. G. H. (1990) The role of oceanatmosphere reorganization in glacial cycles. Quaternary Science Reviews 9. 305-341.

Broecker, W. S., Peteet, D. M. and Rind, D. (1985) Does the ocean-atmosphere system have more than one stable mode of operation? Nature 315. 21-26. 
Broecker, W. S., Kennett, J. P., Teller, J., Trumbore, S., Bonani, G. and Wolfli, W. (1989) Routing of meltwater from the Laurentide Ice Sheet during the Younger Dryas cold episode. Nature 341, 318-321.

Coope, G. R. and Lemdahl, G. (1995) Regional differences in the late glacial climate of northern Europe bascd on coleopteran analysis. Journal of Quaternary Science 10, 391-395.

Dansgaard, W., White, J. W. C. and Johnsen, S. J. (1989) The abrupt termination of the Younger Dryas climatic event. Nature 339, 532-534.

Dansgaard, W., Johnsen, S. J., Clausen, H. B., Dahl-Jensen, D., Gundestrup, N. S., Hammer, C. U., Hvidberg. C. S., Steffensen, J. P., Sveinbjörnsdóttir, Á. E., Jouzel, J. and Bond, G. (1993) Evidence for general instability of past climate from a 250-kyr ice core record. Nature 364, 218-220.

Einarsson, Th. (1968) Jardfraedi, saga bergs og lands. Mál og Menning, Reykjavík.

Einarsson, Th. (1991) Myndun og mótun lands. Mál og Menning, Reykjavík.

Eiríksson, J., Geirsdóttir, Á. and Símonarson, L. (1991) A review of the late Pleistocene stratigraphy of Reykjavík. Quaternary International, 10-12, 143-150.

Feyling-Hanssen, R. W. (1955) Stratigraphy of the marine LatePleistocene of Billefjorden, Vestspitsbergen. Norsk Polarinstitutt Skrifter 107, 1-186.

Grönvold, K., Óskarsson, N., Johnsen, S. J., Clausen, H. B., Hammer, C. U., Bond, G. and Bard, E. (1995) Ash layers from Iceland in the Greenland GRIP ice core correlated with oceanic and land sediments. Earth and Planetary Science Letters 135, 149-155.

Haflidason, H., Sejrup, H. P., Klitgaard, D. and Johnsen, S. (1995) Coupled response of the late glacial climatic shifts of NW-Europe reflected in Greenland ice cores: evidence from the northern North Sea. Geology 23, 1059-1062.

Hjartarson, A. (1989) The ages of the Fossvogur layers and the Álftanes end-moraine. Jökull 39, 21-31.

Hjartarson, Á. and Ingólfsson, Ó. (1988) Preboreal glaciation of Southern Iceland. Jökull 38, 1-16.

Hăkansson, S. (1983) A reservoir age for the coastal waters of Iceland. Geologiska Föreningens i Stockholm Förhandlingar $105,64-67$.

Ingólfsson, O. (1987) Investigations of the Late Weichselian glacial geology of the lower Borgarfjördur region, western Iceland. Lundqua Thesis, 19. 4 pp.+IV appendices.

Ingólfsson, O. (1988) Glacial history of the lower Borgarfjördur area, western Iceland. Geologiska Föreningens i Stockholm Förhandlingar 110, 293-309.

Ingólfsson, Ó. (1991) A review of the Late Weichselian and early Holocene glacial and environmental history of Iceland. In Environmental Change in Iceland: Past and Present, eds J. K. Maizels and C. Caseldine, pp. 13-29. Kluwer Academic, Dordrecht.

Ingólfsson, Ó. and Norddahl, H. (1994) A review of the environmental history of Iceland, $13,000-9000 \mathrm{yr}$ BP. Joumal of Quatemary Science 9, 147-150.

Ingólfsson, Ó., Norddahl, H. and Haflidason, H. (1995) Rapid isostatic rebound in southwestern Iceland at the end of the last glaciation. Boreas 24, 245-259.

Jansen, E. (1987) Rapid changes in the inflow of Atlantic water into the Norwegian Sea at the end of the last glaciation. In Abrupt Climatic Change - Evidence and Implications, eds W. H. Berger and L. D. Labeyrie, pp. 299-310. Reidel, Dordrecht.

Johnsen, S. J., Dahl-Jensen, D., Dansgaard, W. and Gundestrup. N. (1995) Greenland palaeotemperatures derived from GRIP bore hole temperatures and ice core isotope profiles. Tellus 47B, 624-629.

Kaldal, I. and Víkingsson, S. (1991) Early Holocene deglaciation in central Iceland. Jökull 40, 51-66.

Karpuz, N. and Jansen, E. (1992) A high-resolution diatom record of the last deglaciation from the SE Norwegian Sea
Documentation of rapid climatic change. Paleoceanography 7, 499-520.

Karpuz, N. and Schrader, H. (1990) Surface sediment diatom distribution and Holocene paleotemperature variations in the Greenland, Iceland and Norwegian Sea. Paleoceanography $\mathbf{5}$, $557-580$.

Karpuz, N., Jansen, E. and Haflidason, H. (1993) Paleoceanographic reconstruction of surface ocean conditions in the Greenland, Iceland and Norwegian Seas through the last $14 \mathrm{ka}$ based on diatoms. Quatemary Science Review's 12, $115-140$.

Kjartansson. G. (1966) Nokkrar nýjar 14-C aldursákvardanir. Náttúrufraedingurinn 36, 154-171.

Kutzbach, J. E. and Wright, H. E. (1985) Simulation of the climate of 18,000 yr BP: Results for the North American/ North Atlantic/European sector and comparison with the geologic record. Quaternary Science Reviews 4, 147-187.

Kvamme, T., Mangerud, J., Furnes, H. and Ruddiman, W. F. (1989) Geochemistry of Pleistocene ash zones in cores from the North Atlantic. Norsk Geologisk Tidskrift 69, 251-272.

Lacasse, C.. Sigurdsson, H., Jóhannesson, H., Paterne, M. and Carey, S. (1995) Source of Ash Zone 1 in the North Atlantic. Bulletin of Volcanology 57, 18-32.

Long, D. and Morton, A. C. (1987) An ash fall within the Loch Lomond stadial. Joumal of Quaternary Science 2, 97-101.

Lehman, S. J. and Keigwin. L. D. (1992) High resolution record of the North Atlantic drift 14-8 kyr BP: implications for ciimate, circulation and ice sheet melting. Nature 356, 757762 .

Lowe. J. J., Amman, B., Birks, H. H., Björck, S., Coope, G. R., Cwynar, L., De Beaulieu, J.-L., Mott, R. J., Peteet, D. M. and Walker, J. C. (1994) Climatic changes in areas adjacent to the North Atlantic during the last glacial-interglacial transition. Journal of Quaternary Science 9, 185-198.

Mangerud, J., Lic, S. E., Furnes, H., Kristiansen, I. L. and Lømo, L. (1984) A Younger Dryas ash bed in western Norway and its possible correlations with tephra in cores from the Norwegian Sea and the North Atlantic. Quaternary Research 21, 85-104.

Mangerud, J., Furnes, H, and Jóhansen, J. (1986) A 9000-yearold ash bed on the Faroe Islands. Quaternary Research 26, $262-265$

Meese, D. A., Gow, A. J., Grootes, P., Mayewski, P. A., Ram, M., Stuvier, M., Taylor. K. C., Waddington, E. D. and Zielinski, G. A. (1994) The accumulation record from the GISP2 core as an indicator of climate change throughout the Holocene. Science 266, 16801682.

Norddahl, H. (1983) Late Quaternary stratigraphy of Fnjóskadalur, central north Iceland. Lundqua Thesis 12, 78.

Norddahl. H. (1991a) Late Weichselian and Early Holocene deglaciation history of Iceland. Jökull 40, 27-50.

Norddah1, H. (1991b) A review of the glaciation maximum concept and the deglaciation of Eyjafjördur, North Iceland. In Environmental Change in Iceland: Past and Present, eds J. K. Maizels and C. Caseldine, pp. 31-47. Kluwer Academic, Dordrecht.

Norddahl, H. and Ásbjörnsdóttir, L. (1995) Ísaldarlok í Hvammsfirdi. In Eyjar i Eldhafi, eds B. Hróarsson, D. Jónsson and S. S. Jónsson, pp. 117-131. Gott Mál, Reykjavík.

Norddahl, H. and Haflidason, H. (1992) The Skógar Tephra, a Younger Dryas marker in North Iceland. Boreas 21, 23-41.

Pétursson, H. G. (1986) Kvartærgeologiske undersökelser på Vest-Melrakkaslétta, Nordöst-Island. Unpublished Cand. Real. Thesis, Universitetet i Tromsø, Tromsø.

Pétursson, H. G. (1991) The Weichselian glacial history of west Melrakkaslétta, Northeastern Iceland. In Environmental Change in lceland: Past and Present, eds J. K. Maizels and C. Caseldine, pp. 49-65. Kluwer Academic, Dordrecht.

Ruddiman, W. F. and McIntyre, A. (1981) The North Atlantic ocean during the last deglaciation. Palaeogeography, $\mathrm{Pa}$ laeoclimatology. Palaeoecology 35, 145-214. 
Rundgren, M. (1995) Biostratigraphic evidence of the AllerodYounger Dryas-Preboreal oscillation in Northern Iceland. Quaternary Research 44, 405-416.

Rundgren, $\dot{M}$., Ingólfsson, $\dot{O}$., Björck, S., Jiang, H. and Haflidason, H. (1997) Dynamic sea-level change during the last deglaciation of northern Iceland. Boreas 26, 201215.

Sarnthein, M., Jansen, E., Weinelt, M., Arnold, M., Duplessy, J. C., Erlenkeuser, H., Flatøy, A., Johannessen, G., Johannessen. T., Jung, S., Koç. N., Labeyrie, L., Maslin. M., Pflaumann, U. and Schulz. II. (1995) Variations in Atlantic surface ocean paleoceanography, $50^{\circ}-80^{\circ} \mathrm{N}$ : A time-slice record of the last 30.000 years. Paleoceanographv 10, 106.3-1094.

Sejrup, H. P., Sjgholm, J., Furnes, H., Beyer, I., Eide, L., Jansen, E. and Mangerud, J. (1989) Quaternary tephrachronology on the Iceland Plateau, north of Iceland. Jommal of Quatemary Science 4, 109-114.

Sjøholm, J., Sejrup. H. P. and Furnes, H. (1991) Quaternary volcanic ash zones on the Iceland Plateau, southern
Norwegian Seat. Joumal of Quatemary Science 6, 159 173.

Sveinbjörnsdóttir, Á. and Johnsen, S. J. (1991) The late glacial history of Iceland. Comparison with isotopic data from Greenland and Europe and deep sea sediments. Jijkull 40, 8.396.

Sxmundsson, Th. (1995) Deglaciation and shoreline displacement in Vopnafjördur, northeastern Iceland. Lundqua Thesis 33. 106 .

Thouveny, N.. De Beaulieu, J.-I.., Bonifay, E., Creer, K., Guiot, J., Icole, M., Johnsen, S. J., Jouzel, J., Reille, M., Willians, T. and Williamson, D. (1994) Climate variations in Europe over the past $140 \mathrm{kyr}$ deduced from rock magnetism. Nature 371 503-506.

Walker, G. P. L. (1965) Some aspects of Quaternary volcanism in lceland. Transactions of the Leicester Literary and Philosophical Society 59, 25-40. 